\title{
Editorial
}

\section{LETTING REMAINDERS GET STUCK IN OUR THROATS}

What is waste? To my eyes the carton in the middle of a roll of toilet-paper is something to put in the paper recycling bin, whereas my handicraft-minded daughter takes it for the upper-part of the pillar of a castle and my rats use it as construction material for their nest. Apparently, waste is a subjective term. In all three cases one might say it is not waste - really - but a resource. This neatly fits the current social narrative about waste, that takes waste not so much as a problem, but as a resource (Corvellec and Hultman 2012).

In late-capitalism we dream dreams of zero waste and remainder-less recycling, in which everything is put to use and becomes a resource once again in an ongoing circular movement. Things are to be endlessly transformed into new things, that can be exchanged again and again ( $O$ 'Brien 1999). This discourse frames waste as always already managed and manageable (Corvellec 2014), underpins the logic of sustainable growth and helps to frame waste as "an object of manageable sustainability" (Valenzuela and Böhm 2017, 29). As a problem, waste was a stark reminder of the dark side of capitalist consumerism. As a resource, however, all "traces of wastefulness" (Valenzuala and Böhm 2017) disappear and waste loses its critical edge. In short: the resourcification of waste strips it of its power as a doomsayer urging us to curb our consumption.

Instead of framing waste as easily manageable and digestible, I suggest we let it get stuck in our throats. A lozenge offered by the World Bank (2018) last year in the face of the expectation that global waste generation will increase by $70 \%$ by 2050 , puts the (Western) mantra of "reduce, re-use, recycle" very much in perspective. The focus on consumer waste is also very much misleading. Although the often-quoted statistic of $3 \%$ municipal waste to $97 \%$ industrial waste is shady (Liboiron 2016), municipal waste sure isn't our biggest problem. Waste messes with our dreams of (economic) growth without residues and remainders and invites us to reflect on its (in)digestibility. French philosopher Jacques Derrida can help us out here, whose thought on the biodegradable and on "eating well" offers a 'revised metabolic imagery' (Gabrys 2013, 219) which allows us to get a grip on the digestibility of waste.

'What is a thing? What remains? What, after all, of the remains?' (Derrida 1989, 812). With these questions Derrida launches into 'Biodegradables. Seven Diary Fragments' (1989), a text in which he reflects on things degrading and on what remains of them. The "biodegradable thing" has a strange status among things, as it is "hardly a thing, desti- ned to pass away, to lose its identity as a thing and become a non-thing' (Derrida 1989, 813). When we ask about the biodegradability of things, we ask how things that once were something lose their identity and become nothing, non-things. Although Derrida is not concerned specifically with (material) waste-things (he inquires mostly what remains of texts, if one idea, story or view is more degradable than another and wherein does this degradability lie) his thoughts on the biodegradable are also of interest to those concerned with material remainders, that is, with waste. In this I follow Michael Peterson, who argues that Derrida's 'engagement with the survival of texts is at once a thinking through of waste' (Peterson 2018, 253).

Derrida gives us the following definition of the biodegradable: 'to be (bio)degradable means at least two things: on the one hand, the annihilation of identity; on the other hand, the chance to pass into the general milieu of culture, into the "life" of "culture" while enriching it with anonymous nourishing substances.' (838) Biodegradability is, then, all about the ability to lose identity, to fall apart and in so doing become (nourishment for) something else. Derrida relates this process to the function of great works of art in cultures and remarks that they should be both biodegradable (as otherwise they would not be able to enrich and nourish a culture) and 'resist erosion' (845) or, differently put, should be able to be 'assimilated as inassimilable' (845).

What about the word "biodegradable" itself? Derrida calls it an artificial word, made up of both Greek (bios, life) and Latin (degradere, stepping down) and is generally used to refer to products that are artificial and synthetic, 'from plastic bags to nuclear waste' (Derrida 1989, 815). When we speak about biodegradability, we mostly refer to things that resist the process of decay and are non--biodegradable, not so much living [bios] (or dead), but undead. Things get stuck in time and for a certain period are unable to become something else. Biodegradation is always a matter of time. As Michael Naas points out, when we speak of the biodegradable, we usually don't refer to organic things, that is, to things that are and always were able to decompose without technical aid. Nor do we refer to rocks or mineral as nonbiodegradable. The biodegradable thing is, then, 'the name given to a certain category of artificial, industrial, often mass-produced "thing"' (Naas 2015, 193).

Derrida's analysis of biodegradability is, then, all about dealing with the (unwelcome) inheritance of things livingon [sur-vie] after we are done with them. Whereas in works of art we admire that they keep their form, that they remain, we'd rather our waste did not. The biodegradable is, as Der- 
rida puts it, 'on the side of life' (824). That is, in order to give life, to enrich and to nourish, things must be able to lose their identity, their form. This does not mean, however, that the nonbiodegradable - waste - is on the side of death. For the problem of the nonbiodegradable is not that it doesn't "die" - nuclear waste, suggested by Derrida as an example of the 'absolute nonbiodegradable' (863), is finite too - but that it takes a long time to do so. The nonbiodegradable does not so much refer to the dead, but the undead, to things that are in-between life and death. Just like zombies, who refuse to die and continue to haunt us. The nonbiodegradable, then, seems to refer to things getting stuck, things not losing form, things being (in places) we don't want (them) to be and, although undead, continuing to act and demand our care.

How to deal with these remainders? Derrida's concept of "eating well" is of interest here. In an interview in 1991 Derrida reflects on what it would mean to "eat well", referring both to the literal ingestion of substances, of food, and of the figural ingestion of values and ideas and asks how we can learn to do that well. Derrida: 'The moral question is thus not, nor has it ever been: should one eat or not eat, eat this and not that, the living or the nonliving, man or animal, but since one must eat in any case and since it is and tastes good (bien) to eat, and since there's no other definition of the good (du bien), how for goodness sake should one eat well (bien manger)?' (Derrida 1991, 114) Eating well is a social thing. It is not only about what we eat ourselves, but also about what we give to eat. What do we give to eat to future generations? What will they inherit from us? It appears we are offering them a lot of things that are not easily digestible, like plastic and nuclear waste. Just like eating, digesting is a joined event. Digesting is something you do together - without the bacteria that inhabit my microbiome I would not be able to digest a thing. Digestion is about taking in, taking out nutrients for energy, growth, repair and then giving back what remains, that is to become a nutrient for something else.

Waste management should, then, be concerned with the digestibility of waste, that is, the degree in which a material is able to lose its specific form or shape and become something else. Or put differently (and with waste as the "undead" in mind), to deal with remainders and to provide "end-of-life care". Dutch-based Italian researcher and designer Maurizio Montalti explores what this end-of-life care could look like in his art-design project The Ephemeral Icon (2010). This project centers around the monobloc, the classic one-piece plastic chair that we have all sat in at one point in our lives, and asks how this "eternal icon" - the monobloc itself can break down of course, but the plastic it's made of will take a long time to degrade - can be turned into an "ephemeral icon". How to 'infuse life to trigger a process of final dissolution', Montalti asks, and 'dress it up for death'? (Montalti 2010, 48) Montalti experiments with fungi that, as it turns out (in lab conditions), can be tricked into taking plastic for something edible and digesting it (Figure 1).

Since the completion of Montatlti's project in 2010, plastic eating bacteria have been found in the wild (Yoshida et al. 2016) which has even led to the creation of a

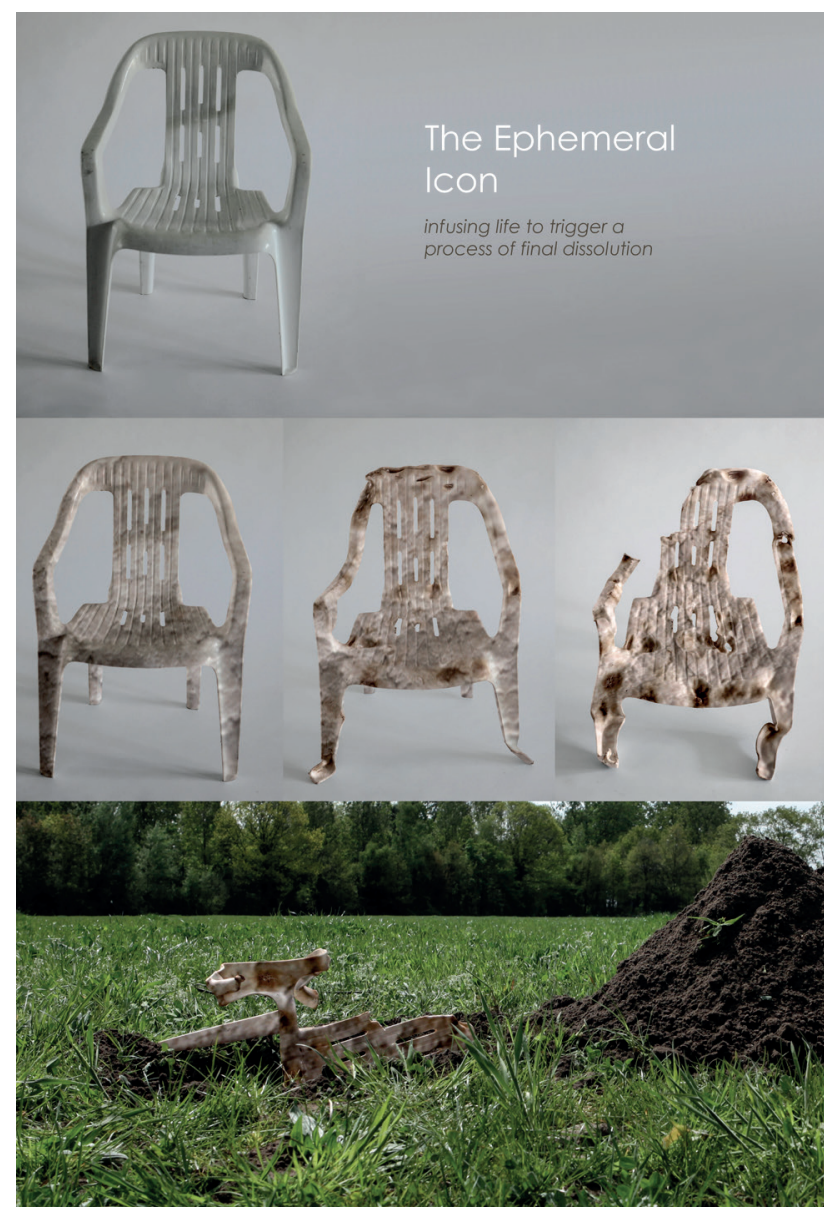

FIGURE 1: Officina Corpuscoli - The Ephemeral Icon - Decomposition Steps CCCorpuscoli_Montalti.

"mutant enzyme" that appears to be very skilled in eating PET (Austin et al. 2018). Have we entered the era of eating well? And if bacteria are starting to eat plastics, don't they help us close the loop, similar to what a resourceapproach to waste does? Biodegradability does seem to present 'an ideal vision of matter, lapsing back into "nature" without leaving a visible residue' (Gabrys 2013, 216) and in so doing naturalize plastic and construe it as nonproblematic matter. The 'recalcitrance of plastic' (Gabrys $2013,216)$, however, ensures that this does not run smoothly. As Jennifer Gabrys point out, reflection on biodegradability points to a 'more collective understanding of material processes' (218). These plastic eating bacteria are unruly, they evolved without our help in the garbage dump in which they were found and will probably evolve and live on to do unexpected things. There is no closing the loop in such an ongoing and collective process. We could also ask if letting other organisms deal with our waste is yet another way of dumping our waste in a vulnerable, less powerful community and avoid taking responsibility for it. Instead, we should try and learn to live with it.

Derrida's notion of "eating well" is about recognizing the way in which we are connected to and interdependent with processes that fall outside our control and learn to eat and give to eat as best we can within these interdependencies. 
And let's not forget that eating well is about what comes out at the back end - too. We can wipe our asses, flush the toilet and put the remaining carton in the recycling bin and convince ourselves all will be re-assimilated, or we could take another look back and really deal with our shit.

\section{Lisa Doeland *}

Radboud Universiteit Faculteit der Filosofie Theologie en Religiewetenschappen, Radboud Reflects, The Netherlands

*I.doeland@reflects.ru.nl

\section{REFERENCES}

Austin, H.P, D.M. Allen, B. S. Donohue et al. (2018) 'Characterization and engineering of a plastic-degrading aromatic polyesterase', PNAS, 115(19): E4350-E4357.
Corvellec, $\mathrm{H}$ and J. Hultman (2012) 'From "less landfilling" to "wasting less": Societal narratives, socio-materiality, and organizations', Journal of Organizational Change Management, 25(2): 297-314.

Corvellec, H. (2014) 'Recycling food waste into biogas, or how management transforms overflows into flows', in C. Barbara and L. Orvar (eds.), Coping with excess. How organizations, communities and individuals manage overflows, 154-172. Cheltenham: Edward Elgar Publishing.

Derrida, J. (1989) 'Biodegradables. Seven Diary Fragments', Critical Inquiry, 15(4): 812-873.

Derrida, J. (1991) "Eating well", or the calculation of the subject: an interview with Jacques Derrida', in E. Cadava, P. Conner and J-.L. Nancy (eds.), Who comes after the subject?, 96-119. London: Routledge.

Gabrys, J. (2013) 'Plastic and the work of the biodegradable', in J. Gabrys, G. Hawkins and M. Michael, Accumulation. The material politics of plastic, 208-227. London and New York: Routledge.

Kaza, S., L. Yao, P. Bhada-Tata and F. van Woerden. (2018) What a Waste 2.0. A Global Snapshot of Solid Waste Management to 2015. Washington, DC: World Bank. 